\title{
NBSIR 87-3576
}

\section{The ABC's of Standards-Related Activities in the United States}

Maureen A. Breitenberg

U.S. DEPARTMENT OF COMMERCE

National Bureau of Standards

Standards Code and Information

Office of Product Standards Policy

Gaithersburg, MD 20899

May 1987

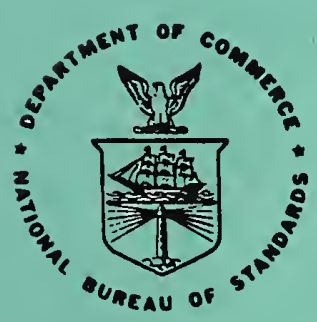

U.S. DEPARTMENT OF COMMERCE

QC

L BUREAU OF STANDARDS

100

456

\#87-3576

1987

c. 2 

NBSIR 87-3576

The ABC'S OF STANDARDS-RELATED

ACTIVITIES IN THE UNITED STATES

Maureen A. Breitenberg

U.S. DEPARTMENT OF COMMERCE

National Bureau of Standards

Standards Code and Information

Office of Product Standards Policy

Gaithersburg, MD 20899

May 1987

U.S. DEPARTMENT OF COMMERCE, Malcolm Baldrige, Secretary NATIONAL BUREAU OF STANDARDS, Ernest Ambler, Director 
Eoreword

The Standards Code and Information Program in the NBS Office of Product Standards Policy from time to time develops and publishes standards-related documents as a service to producers and users of standards and certification systems, both in the government and in the private sector. This report has been designed as an introduction to standardization, certification, and laboratory accreditation for those not fully familiar with these fields and their interrelationships. We hope that this material will be informative and will also serve to stimulate wider and more profitable applications of standardization. In addition, the interested reader may wish to take further advantage of other available publications and services provided by this office, some of which are described in the appendix.

Donald R. Mackay

Manager, Standards Code and Information

office of Product Standards Policy 



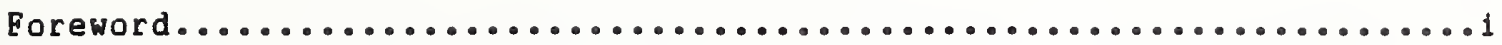

Acknowledgements.....................................11

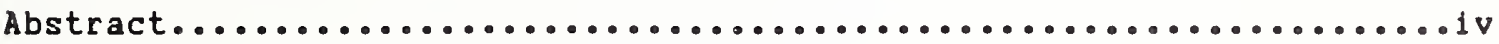

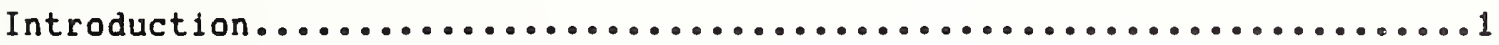

Background...........................................

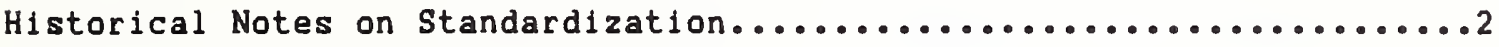

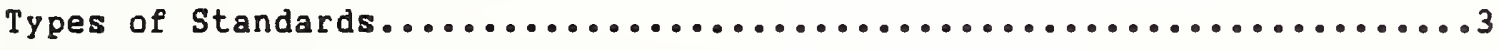

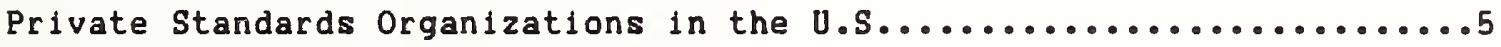

Standards Development Procedures...........................

Benefits and Problems of Standardization.......................

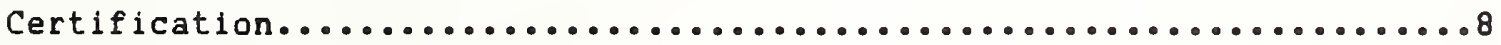

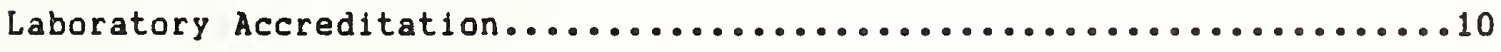

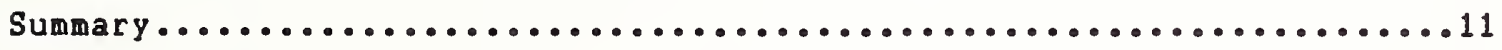

Appendix............................................

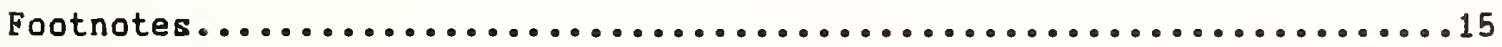




\section{Acknowledgements}

I would like to thank Tom Kelsey. International Trade Administration; dipl. Ing. Alfonse F. Donko, Deputy Managing Director, Osterrelchisches Normungsinstitut (ON), and many others for their careful review of and comments on this document.

I would especially like to thank Walter Lelght, OPSP, who oversaw the preparation of many of the initial drafts of this document. 
. 
Abstract

This report provides an introduction to voluntary standardization, product certification and laboratory accreditation for a reader who is not fully familiar with these topics. It highlights some of the more important aspects of these fields; furnishes the reader with both historical and current information on these topics; describes the importance and impact of the development and use of standards; and serves as background for using avallable documents and services.

Key Words: Certification; inspection; laboratory accreditation; standardization; standards; testing 

Introduction

"The inch is a standard of measurement. Money is a standard of exchange. Words are standards of communication. Traffic lights are safety standards. Octane numbers of gasoline are guality standards. 'No more than 1 iz shrinkage' is a performance standard." 1 /

As the above indicates, standardization has a major impact on our lives, yet most people know little about the process or about the standards themselves. They know that camera film marked ISO 100 is likely to give good results in a camera with the film speed set at 100, but few understand that the ISO 100 marking on the package means that the film conforms to a standard established by the International Organization for Standardization (ISO), an international organization that writes standards. Bew people question that three-holed notebook paper will align with the three rings in most notebooks, yet such confidence would not be possible without standards. While driving we are on the lookout for hexagonal, not round or square-shaped stop signs, just as we know that inverted triangles indicate where traffic should yield. These are just a few of the thousands of standards that impact on our lives.

Because standards have such an impact, it is important to have some familiarity with what they are and how they are developed and used. This paper is designed to be an introduction to some of the more significant aspects of standards development, product certification, and laboratory accreditation. It will also discuss some of the benefits and problems associated with these processes. The interested reader is encouraged to increase his knowledge of the field by taking advantage of other available publications and services described in the appendix.

\section{Background}

A standard was defined by the National Standards Policy Advisory Committee as:

"A prescribed set of rules, conditions, or requirements concerning definitions of terms; classification of components; specification of materials, performance, or operations; delineation of procedures; or measurement of quantity and quality in describing materials, products, systems, services, or practices." $\underline{2}$ I

Though often unrecognized, standards can help to assure health and safety and to increase the quality of life. Standards are vital tools of industry and commerce. They often provide the basis for buyer-seller transactions, hence they have tremendous impact on companies and nations, and even on the economic fabric of the world market.

In the United States alone, approximately 30,000 current voluntary standards have been developed by more than 400 organizations. These do not include a much greater number of procurement specifications (developed and used by Federal, State, and local procurement authorities), as well as mandatory codes, rules and regulations containing standards developed and adopted at Bederal, 
State, and local levels. In addition, numerous foreign national, regional and international organizations produce standards of interest and importance to U.S. manufacturers and exporters.

There are numerous international organizations that produce standards. The International Organization for Standardization (ISO) probably produces the largest number of International Standards, having issued approximately 6,000 standards. ISO's work is carried out through some 2,300 technical bodies in which more than 20,000 experts from all over the world participate annually in the development of ISO standards.

The international General Agreement on Tariffs and Trade (GATT) has as one of its major components the Agreement on Technical Barriers to Trade (usually referred to as the Standards Code). The framers of the Standards Code recognized that standards and standards-related activities can serlously hinder the free flow of goods in international commerce. The Code established, for the first time, some requirements for the procedures by which standards are developed, adopted, and used and for the systems which determine conformity with such standards.

The Trade Agreements Act of 1979 implemented the Standards Code in the United States. Federal agencies are required under the Act to:

"-Not engage in standards activities that are prepared, adopted or applied to create, or have the effect of creating, unnecessary obstacles to the foreign trade of the United States;

-Ensure that imported products are treated no less favorably than domestic products;

-Use international standards, if appropriate, as a base for developing new standards;

-Develop standards based on performance rather than design criteria, if appropriate; and

- Allow foreign suppliers access to their certification systems on the same basis as access is permitted to domestic suppliers." $3 /$

Historical Notes on Standardization

The history of standardization is both fascinating and demonstrative of the scope and varlety of such activities. A predecessor of the American National Standards Institute (ANSI) noted that one of the first known attempts at standardization in the Western world occurred in 1120. King Henry I of England ordered that the ell, the ancient yard, should be the exact length of his forearm, and that it should be used as the standard unit of length in his kingdom. 4 /

That history also notes that, in 1689, the Boston city fathers recognized the need for standardization when they passed a law making it a civic crime to manufacture bricks in any size other than $9 \times 4 \times 4$. The city had just been destroyed by fire, and the city fathers decided that standards would assure rebuilding in the most economic and fastest way possible. $\underline{5}$ 
Eli Whitney is sometimes referred to as "the Father of Standardization" in the area of interchangeability, having originated and implemented the concept of mass production in the United States in 1780. He was awarded a contract to produce 10,000 muskets by then Vice-President Thomas Jefferson. Though standardized parts had been successfully used in other parts of the world, Whitney brought the concept to this country when he divided the manufacturing process into individual steps and put different groups to work on each step of the process. All parts of the same type were copied from a model musket and were made to be interchangeable. Subsequently, when he appeared before Congress with a collection of assorted parts and proceeded to assemble ten working muskets by selecting the required parts at random, Congress was convinced of the benefits of mass production made possible by standardization. $6 /$

Standards are known to have existed as early as 7000 B.C. when cylindrical stones were used as units of weight in Egypt. However, the great blaze in downtown Baltimore in February 1904 and other, similar catastrophes provided tragic and undeniable evidence of the importance of standards. While the fire in Baltimore burned, fire engines frow as far away as New York rushed to the scene only to discover that their hoses would not fit Baltimore hydrants. Those "alien" fire engines were useless! The inferno burned for more than thirty hours, destroying 1526 buildings covering more than seventy city blocks. All electric light, telephone, telegraph, and power facilities were also razed. I/ In contrast, 23 years later, help from 20 neighboring towns saved Fall River, Massachusetts from destruction since hydrants and hose couplings had been standardized in these communities. 8 /

As late as 1927, a color-blind motorist had as good (or as bad) a chance as anyone else when trying to interpret traffic signals. Purple, orange, green, blue, yellow, and red lights greeted him as he drove from state to state. In some states, green meant "Go," in others "Stop." Red, not yellow, lights meant caution in New York City. In 1927 a national code for colors was established through the work of the American Association of State Highway officials, the National Bureau of Standards and the National Safety Council. g/ Imagine the chaos that would occur during rush hour in any major U.S. city today if newcomers and tourists did not know what traffic signals meant!

Probably the most significant standard ever developed in the United States, however, was the railroads' standard track gage. This standard, now used in Great Britain, the U.S., Canada and much of continental Europe, enables railroad rolling stock to cross the country. 10/

It was the Second World War, however, that brought the urgency of extending domestic standardization to the international level. Allied supplies and facilities were severely strained because of the incompatibility of tools, replacement parts, and equipment. The War highlighted the need for standards aimed at reducing inventories and increasing compatibility.

\section{Typer of Standards}

Standards nay be classified in numerous ways, some of which are described here. Iso Draft Guide 2 differentiates eight types based on purpose. $11 / \mathrm{A}$ basic standard has a broad ranging effect in a particular field, such as a standard for metal which affects a range of products from cars down to screws. Terminology 
gtandards defing words permitting representatives of an industry or parties to a transaction to use a comon, clearly understood language. Testing standards define the test nethods to be used to assess the performance or other characteristics of a product. Product standards establish qualities or requireaents for a product (or related group of products) to assure that it will serve its purpose effectively. Process standards specify requirements to be met by a process, such as an assembly line's operation, in order to function effectively. Service standards, such as for servicing or repairing a car, establish requirements to be met in order to achieve the designated purpose effectively. Interface standards, such as the point of connection between a telephone and a computer terminal, are concerned with the compatibility of products. The last type provides a listing of data requirenents for a product or service for which values need to be obtained.

Standards may also be classified by the intended user group. These classifications range from compang standards, meant for use by a single industrial organization, to international standards. International standards are developed and promulgated by international governmental and non-governmental organizations, such as the North Atlantic Treaty Organization's (NATO's) Military kgency for Standardization (governmental) and the ISO (non-governmental). International standards may be voluntary or mandatory in nature. A harmonized standard, on the other hand, can be either an attempt by a country to make its standard compatible with an international, regional or other standard or it can be an agreement by two or more nations on the content and application of a standard, the latter of which tends to be mandatory. Harmonized standards may also be identical in content to other standards. There are still other classifications such as industry standards, developed and promulgated by an industry for materials and products related to that industry; and military or government standards, such as those designed to be used by the Department of Defense or by the Federal Government. These should not be confused with Federal and Military Specifications, used by the Federal Supply Services in the General Services Administration and by the Department of Defense respectively. Specifications are a set of conditions and requirements that provide a detailed description of a procedure, process, material, product, or service for use primarily in procurement and manufacturing. $12 /$

Another distinction among standards is the manner in which they specify requirements. Those standards that describe how a product is supposed to function are called performance standards. In contrast, design standards define characteristics or how the product is to be built. For example, a performance standard for water pipe might set requirements for the pressure per square inch that a pipe must withstand, along with a test method to determine if a specimen meets the requirement. On the other hand, the specification that a pipe be made of a given gage of copper would characterize a design standard. The distinction, however, between these two types of standards is not always clear cut. It is possible to include two different requirements within the same standard, one of which is stated in terms of performance and the other in terms of design. For example, in a standard for copper pipe, requirements for the pipe can be specified in terms of its performance (being able to withstand a given amount of pressure), but the same standard may require that the pipe's flanges or couplings meet specific design requirements. 
Design standards aay be appropriate, as in testing methods where the need for comparability may outwelgh other conslderations. In general, however, performance standards, though usually more dfficult to write and enforce, tend to be less restrictive than design standards, and more likely to encourage innovation. For that reason, signatories to the Standards Code are encouraged to write technical regulations and standards in terms of performance, rather than design, characteristics.

Still another classification scheme distinguishes between voluntary standards, which by themselves iapose no obligations regarding use, and aandatory

standards. A mandatory standard 18 generally published as part of a code, rule or regulation by a regulatory government body and imposes an obligation on specified parties to confor to 1t. However, the distinction between these two categories may be lost when voluntary consensus standards are referenced in government regulations, effectively aking them "mandatory" standards. Voluntary consensus standards may also becone "quasi-mandatory" due to conditlons in the marketplace. For example, the health care industry is sensitive to the need to have avallable the safest products to ensure patlent safety and to protect manufacturers, vendors and health care provlders against lawsults. Informed buyers of health care products will frequently insist that products aeet all approprlate voluntary consensus standards. If they wish to compete effectively, manufacturers of such products are obliged to confor to such standards.

It is clear, then, that standards cover a broad range of types and serve a wide varlety of purposes.

\section{Private Standards Organizations in the 0.S.}

The need for safe and econosical structures, such as roads and bridges, led to the founding of the International Association for Testing and Materials in 1896. Its aission was to develop standardized test methods. Two years later, the American Section of this organization was formed and became the porerunner of the American Society for Testing and Materials, now known as ASTM. Since becoming an independent organization in 1902, ASTM has continued to grow and now produces the largest number of non-governmental, voluntary standards in the United States.

In 1918, ASTM was one of flve private, technical society originators of the American Engineering Standards Comittee, later to be known as the American Standards Association (ASA), and subsequently as the American National Standards Institute (ANSI). ANSI today serves as the coordinator of voluntary standards activities in the United States and as the agency that approves standards as American National Standards. ANSI is also the coordinator and aanager of U.S. particlpation in the work of two non-governmental, international standards organizations, ISO and the International Electrotechnical Comission (IEC).

Another of the major private standards organizations, the American Society of Mechanical Englneering (ASME), was founded in 1880 and first 1ssued the ASME Boiler Code in 1914. Today that Code is mandatory not only in the United States, but in aany other countries throughout the world. In 1952, a forerunner of ANSI stated: "Probably no other single standard in America has done more for national safety than the ASME Boller Code." $13 /$ The ASHE Boiler Code may be the most widely used voluntary standard in the world. 
The founding of the Society of Automotive Engineers (SAE) in 1910 led to the pioneering efforts of the American automotive industry to achieve substantial inter-company technical standardization. Most drivers now take these efforts for granted when choosing motor olls by SAE designations (such as 10W-40) without being aware of the full significance and background of the detailed standards development process.

Most consumers also take for granted the familiar UL mark on a range of products from electrical appliances to fire extinguishers. The Underwriters Laboratories (UL), founded in 1894, is not only a major standards wrlter, but also operates non-profit testing laboratories whose mission is to investigate products and materials with respect to hazards that might affect life or property and to list those items which appear to pose no significant hazards.

The work of other major standards organizations, although equally vital, tends to be less well known outside the standards community. For example, the National Fire Protection Association (NFPA) has for more than three quarters of a century produced the National Electrical Code, used in bullding construction, and many other standards affecting our safety from fires and other hazards. We accept without conscious thought the safety of aircraft unaware of the standards produced by the Aerospace Industries Association of America (AIA) for guidance and control systems and many other items. The Assoclation of American Railroads' (AAR) standards similarly affect our railroads. Even the quality and size of paper is standardized through the work of the Technical Association of the Pulp and Paper Industry (TAPPI).

In all, more than $\$ 00$ organizations develop voluntary standards of many different types for a broad range of services, products, and tests. Some organizations, such as ANSI and ASTM, are primarily concerned with standards. Others are trade associations interested in all matters affecting their members. The Electronic Industries Association, for example, has been a standards developer in the areas of electrical and electronic products and components since 1926.

Many professional and technical organizations are also standards developers. The Institute of Electrical and Electronics Engineers (IEEE), which traces back to 1884, maintains more than 500 standards with 800 more under development. IEEE is responsible for the National Electrical Safety Code, widely used by governments and regulatory agencies for electric supply and communications installations. Still other standards developers are primarily research and testing bodies, such as the National Sanitation Foundation (NSF), which develops standards for products from a health and sanitation perspective. The Factory Mutual Research Corporation (FM), another standards developer, is a "product listing" type of organization, as is UL.

In addition, bullding code organizations, such as the Building officials and Code Administrators International (BOCA), the International Conference of Building Officials (ICBO), and the Southern Bullding Code Congress International (SBCCI), are involved in standards development. These organizations are composed of building, construction, zoning, and inspection officials; they have developed model building codes adopted by thousands of State and local governments. 
The broad range of organizations participating in standards development reflects the impact standards have on a vast spectrum of interests and disciplines.

\section{Standards Development Procedures}

Two of the most widely used procedures for assuring consensus in the development of standards are the committee and the canvass methods.

Committee Method. Committee standards are subject to wide review and consideration by all interested parties. The requirements of this process vary among organizations. In some organizations, consensus may be defined as an agreement of at least 518 of the participants. Other organizations may also include requirements for due process, appeals procedures, the mandatory consideration of negative votes or comments, and for "comittee balance." Balance is achieved when all parties having an interest in the outcome of a standard have an opportunity to participate and where no single interest can dominate the outcome. Standards organizations differ widely in the emphasis placed on each of these requirements. Organizations which emphasize all four factors, in addition to the achievement of substantial agreement among particlpants, produce standards that are more likely to be adopted and used.

Canvass method The "canvass" method is frequently used by an organization that has prepared a standard under 1 ts own internal procedures. To galn greater stature and acceptance of the drafted standard, the developer may then submit it to balloting by a set of organizations representing a variety of interests, such as manufacturers, consumers, government, and others. Any objections or comments from organizations on the "canvass 11 st" must be addressed and satisfactorily resolved. Changes in a proposed standard, as well as any unresolved objections and the developing organization's rationale for its response, must be resubmitted to the "canvass list." It is crucial that all interested groups be included on the list. Two problems sometimes arlse: the response level may be low and consumers and others on the "canvass 1ist" may have difficulty commenting on a standard, because they did not participate in the initial drafting and may not understand the reasons for or implications of particular provisions.

\section{Benefits and Probleas of Standardization}

On the whole, the benefits of standardization far outweigh the difflculties and potential for abuse. Standards promote understanding between buyer and seller and make possible mutually beneficial commercial transactions. Product attributes cannot always be evaluated by individual purchasers by inspection or even from prior experience. However, a product's conformance to accepted standards readily provides an efficlent method of conveying complex information on the product's suitability. Architects use standards in a shorthand manner when drafting plans for bulldings; purchasing agents can also use standards as an easy way of communicating their needs to potential suppliers. In a host of situations standards are or may be used to replace large quantities of complex information.

Standards underlle mass production methods and processes. They promote more effective and organized social interaction, such as the example of the standardized colors for traffic lights and many other widely accepted conventions. Standards are essential in efforts to improve product safety and a to clean up the environment. Standardized and interchangeable parts can reduce inventory requirements and facllitate product repairs. They can also promote 
fair competition by facilitating the comparison of prices of standardized comodities.

In general, standards permit society to make more effective use of its resources and allow more effective comunication among all parties to particular activities, transactions, or processes. Indeed, standards are crucial to every form of scientific and industrial process. Wlthout standards, the quality of iffe would be significantly reduced.

No system, particularly one as complex and diverse as the U.S. voluntary standards system, is without problems. In a recent case of great significance, the United States Supreme Court on May 17, 1982, rendered 1ts decision in favor of Hydrolevel, a manufacturer of low-water fuel cutoff devices, in the case of American Society of Mechanlcal Engineers (ASME) v. Hydrolevel. It found ASME liable for conspiring to restrain trade since two subcomaltee officers, serving as volunteers but acting in the name of ASME, issued a misinterpretation of a standard and produced an adverse effect on the competitiveness of the plaintiff. Similarly, the Eederal Trade Commission held hearings on standards and certification and uncovered "substantiated complaints of individual standards and certification actions that have, in fact, unreasonably restrained trade or deceived or otherwise infured consumers." 14 /

In part, problems result from the sometimes substantial costs of participation in standards development, making it difficult (if not impossible) for small firms and non-industry representatives to be active in the process. The standards themselves may cause problems if highly technical in nature. It is frequently difficult, if not impossible, to get qualified consumer representatives to participate actively. This seriously complicates the attempts to achieve balanced representation by all interests concerned.

Other problems may occur when a standard undergoes review and revision. Unless the original writers of the standard participate in its revision, the reviewers may not be able to understand how the document was prepared, what was eliminated from consideration, and the reasons or assumptions underlying decisions and the resultant provisions. Problems can also occur in the application of specific provisions if the intent behind them is unclear. Rationale statements, which sometimes accompany a standard, are specifically designed to define the purpose and scope of the standard, to explain the criteria used in developing its requirements and to provide all other relevant information at the disposal of the developers. However, the use of rationale statements is not yet extensive. $15 /$

\section{Certiflcation}

"The first time a craftsman claimed that his product met a comanly accepted standard, the most basic form of certification came into being." $16 /$ Today product certification schemes range from the simple to the complex. The hallmarking of precious metals was an early form of certification. Many early attempts, most unsuccessful, were also made to certify weights and measures to provide a uniform basis for the exchange of goods. Now there are over 100 private organizations and over 60 Eederal programs in the United States which certify products ranging from electrical cords to kitchen cabinets. In addition, many certification programs are operated at the state and local level. Consumers see evidence of the extensiveness of certification when they note the Underwriters' Laboratory (UL) certification mark on many products ranging from coffee potsto fire extinguishers; the U. S. Department of Agriculture 
(USDA) mark on meats, poultry and other agricultural products; and the International Wool Secretariat's Woolmark and Woolmarkblend on wool or wood blend textile goods. These are only a few of the many certification programs which are conducted in the United States.

Product certification is intended to confirm that a particular product conforms to one or more specified standards, thus providing the user with explicit or implicit information about the characteristics and/or performance of the product. Certification is a method for increasing a buyer's confidence in a product and for furnishing product information.

In the U.S., if a manufacturer or supplier attests to the fact that his product meets one or more standards, the process is called self-certification. This process is also known as a manufacturer's declaration in other parts of the world. The manufacturer's capability, integrity, and reputation determine the degree of confidence that can be placed in self-certification.

Third-party certification is the term applied to the process by which an organization, independent of either the manufacturer or supplier, assesses the product's conformance to one or more standards. A manufacturer's overall quality control program may also be examined as part of the certification process. $A$ guality control program is a series of activities designed to assure that quality is being maintained at all phases of production. There are hundreds of third-party certification programs in the United States operated by Federal, State, and local governments and by many private organizations. Third-party certification programs differ greatly from one another, and the degree of confidence in the resultant certification depends on the program's type and comprehensiveness.

The methods used in third-party certification programs can be classified as follows:

- Type-testing/Initial Inspection - This assures that the manufacturer's design specifications can produce a product that conforms to a particular standard. Products from a production run are not inspected or tested, and there is no information on whether products from a production run also consistently meet the specification.

- Audit-Testing - In this procedure, test samples are selected at random from the marketplace. Extensive testing is usually reguired to provide adequate assurance that products meet the desired standard.

- Surveillance of the Manufacturing Process - Assessment of a manufacturer's production and control processes can, at relatively low cost, provide assurance that the manufacturer's quality control procedures are adequate.

- Eleld Investigations - Alleged fallures of products under use conditions are investigated to determine the cause of failure and to suggest appropriate corrective action. 
- Batch-testing - A sample of products is selected from a production batch and tested for conformance to the standard. If the sampling procedure and the sample size are adequate, batch-testing makes it likely that all products in that batch conform to the standard. It does not, however, ensure that a specific untested product in the batch will meet the standard nor does it furnish information on the quality of products produced in earlier or subsequent batches. Batch testing is used in many certiflcation programs for bullding products, such as those for energy conservation.

- 100 Percent Testing - Each individual product is tested to determine if it meets the designated standard. If the testing procedures are adequate, the procedure provides the highest possible level of assurance that the product conforms to a particular standard. It is also usually the most expensive method and can be applied only where the test has no adverse effect on the product. $17 /$

Many programs apply two or more of these methods in their certiflcation process. The choice of methods depends on the needs of both the buyer and the seller and the nature of the product. The methods chosen can greatly affect both the cost of the progran and the level of confldence that can be ascribed to $1 t$. ANSI and ISO have each developed criteria to evaluate certification prograns. ANSI has also developed a program to accredit certification schemes which meet its criteria, but only two programs have been accredited to date.

\section{Laboratory Accreditation}

Laboratory accreditation is a process for evaluating testing facilities and designating those laboratories judged competent to perform specific tests using standard test methods, where avallable. The National Voluntary Laboratory Accreditation Program (NVLAP) in the National Bureau of Standards, Department of Commerce, and the American Association for Laboratory Accreditation (AALA) are the two largest accreditation agencies in the United States. There are many other Federal, State and local government programs, as well as many private sector laboratory accreditation programs. Some of these include: the Department of Defense's (DOD) programs for accrediting laboratories which test products which will later be sold to DOD; the State of Massachusetts programs for accrediting concrete testing laboratories and laboratories which test solid fuel burning appliances; and the National Kitchen Cabinet Association's (NKCA) accreditation program for laboratories which test kitchen cabinets as part of the NKCA's certiflcation program. 18/

It should be emphasized that laboratory accreditation assesses the capability of a laboratory to conduct testing, generally using standard test methods. The accreditation process should not be confused with certification nor with the validation of a certification, which is "an action by a third party to assure that the producer (or certifier) is adhering to the requirements of a given certification program." $19 /$ Laboratory accreditation nelther reviews nor assesses products, nor does it check the tests conducted on specific products or product batches. In addition, laboratorles may be accredited to conduct tests (such as EPA's accreditation program for laboratories testing drinking water) in fields where no certification program exists.

Laboratory accreditation, however, can affect the quality of certiflcation programs by requiring evidence that a certifying laboratory has competent personnel, adequate equipment, and sufficient knowledge of the testing 
procedures for which accreditation is sought. Also, laboratory accreditation is assuming increased importance in trade. As countries seek acceptance of their test data by trading partners, they must assure that the data comes from competent laboratories. Laboratory accreditation can help to provide that assurance.

\section{Sumary}

Standardization, product certification, and laboratory accreditation are closely linked. In many developing countries, all three activities are conducted by the same organization. Certiflcation prograas are communication tools designed to reduce the cost of exchanging information between buyer and seller. The quality of the information conveyed depends on both the competence of the testing laboratory selected and the adequacy and appropriateness of the standards against which the product is to be evaluated. Certification can result in widespread consumer deception if performance characteristics or test methods contalned in the standard are insufficient to assure adequate product performance or if the testing laboratory is incompetent or has biases which affect the reporting of test results.

Considering the number of standards in existence and the varlety of fields covered by private sector standards development and certification organizations, the United States has one of the most developed and complex standardization and certification systems in the world. Furthermore, the number of Federal, state, and local government standardization and certification activities and the large volume of standards, regulations, and procurement specifications that these agencies have developed, result in an immense impact of standardization and related activities on almost every aspect of 11 fe in the United States. Not only are considerable resources invested in this country in such activitles every year, but purchasers (consumers) depend on standards and certification to ensure that products purchased are safe and perform satisfactorily. Recognition of the impact of standards and certification on trade, as evidenced by the standards Code, is also increasing. Society depends on standardization and related activities for its existence. 


\title{
APPEADIX
}

\author{
Information Avallable sroe \\ The Standarda Code and Information (8CI) Prograe \\ National Bureau of Standarde \\ Adainietration Bullding, Roon $\mathbf{A 6 2 9}$ \\ Galthersburg, MD 20899 \\ (301) $975-1040$
}

- Directory of International and Regional Organizations Conducting

Standards-Related Activities (NBS SP 649)

Directory contains information on 272 international and regional organizations which conduct standardization, certification, laboratory accreditation, or other standards-related activities. Volune describes their work in these areas, as well as the scope of each organization, national affiliations of meabers, D.S. participants, restrictions on membership, and the avallability of any standards in English.

- Standards Activities of Organizations in the United States (NBS SP 681)

The directory summarizes the standardization activities of sore than 750 organizations in the United States, including Federal and State agencies and approximately 420 private sector groups that develop standards. It also contains listings of State procurement offices, sources of standards documents and information, a subject index and related listing that cover acronys and initials, defunct bodies and organizations with name changes.

- Private Sector Product Certification Programs in the United States (NBS SP 703)

Th1s directory presents infornation from 109 private sector organizations in the United States which engage in product certification activities. Entries describe the type and purpose of each organization, the nature of the activity, products certified, standards used, certification requirements, availability and cost of services, and other relevant detalls.

\section{- Bederal Government Certification Programs for Products and Services \\ (NBS SP 714)}

This directory presents information on $61 \mathrm{U.S}$. Government certification programs for products and services. Entries descrlbe the scope and nature of each certification progran, testing and inspection practices, standards used, aethods of identification and enforcement, reciprocal recognition or acceptance of certification, and other relevant detalls.

- KWIC Index (Computer Output Microfor (COM) produced)

The KWIC Index contains the titles of more than 25,000 U.S. voluntary product and englneering standards. A standard can be located by means of any significant or key word in the title. Key words are arranged alphabetically. A standard with five key words, for example, would therefore be listed in five different places. To purchase aicrofiche copies of the 1987 revision of the Index, contact the National Technical Information Service, 5285 Port Royal Road, Springfield, VA 22161; (703) \$87-4600. Use order no. PB87-133377; cost is $\$ 18.00$ for purchasers in the U.S. 
This newsletter provides information on government programs and available services established in support of the GATT Agreement on Technical Barriers to Trade (Standards Code). tbt news reports on the latest notifications of proposed foreign regulations; bilateral consultations with major U.S. trade partners; programs of interest to U.S. exporters; and availability of standards and certification information. Subscription is free upon request.

- Technical Barriers to Trade

This booklet explains the basic rules of the international Agreement on Technical Barriers to Trade negotlated during the Tokyo Round of the Multilateral Trade Negotiations (MTN), and describes Title IV of the U.S. Trade Agreements Act of 1979 which implements the United States' obligations under the Agreement. The Agreement, popularly known as the Standards Code, was designed to eliminate the use of standards and certification systems as barriers to trade. The booklet describes the functions of the Departments of Commerce and Agriculture, the office of the U.S. Trade Representative, and the State Department in carrying out the U.S.'s responsibilities.

- "GATT Standards Code Activities"

This brochure gives a brief description of NBS' activities in support of the Standards Code. These activities include operating the U.S. GATT inquiry point for information on standards and certification systems; notifying the GATT Secretariat of proposed U.S. regulations; assisting U.S. Industry with trade-related standards problems; responding to inguiries on foreign and U.S. proposed regulations; and preparing reports on the Standard Code.

- Report to the United States Congress on the Agreement on Technical Barriers to Trade - "Standards Code"

This 2nd triennial report describes the programs and activities established to implement the Standards Code in the United States by the four responsible U.S. government agencies: Office of the U.S. Trade Representative; Department of Commerce (National Bureau of Standards, International Trade Administration); Department of Agriculture and Department of State.

- Free handout material on the Office of Product Standards Policy's (OPSP), the National Center for Standards and Certification Information's (NCSCI) and GATT activities, and standards-related information such as: Government sources of specifications and standards, use of the KWIC index, foreign and international standards bodies, U.S. standards organizations, State purchasing offices, NCSCI fact sheet and its certification rules activity, and OPSP publications list (bibliography).

In addition to general inquiry services, the following assistance is also avallable:

- GATT Hotline

A telephone hotline provides current information received from the GATT Secretariat in Geneva, Switzerland, on proposed foreign regulations which may significantly affect trade. The recorded message is updated weekly and gives the product, country, closing date for comments (if any) and Technical Barriers to Trade (TBT) notification number. The hotline number is (301) 975-4041 (not toll-free). 
- Assistance to U.S. and foreign exporters -- Current regulations and certification information for the manuacture of products in the U.S. for export are obtained from foreign countries. To aid foreign exporters, NCSCI provides directory information on State offices prepared to respond to queries concerning conditions to be met by goods for sale in their state, as well as standards and certification information for export to the U.S. 
1/ USA Standards Institute, "What is ... a Standard? the USA Standards Institute? a USA Standard?," USA Standards Institute, New York, New York, p. 1.

2) National Policy on Standards for the United States and a Recommended Implementation Plan, National Standards Policy Advisory Committee, Washington, D.C.,December, 1978. p. 6 .

3/ International Trade Administration, The Tokyo Round Agreements: Technical Barriers to Trade - Volume 4, Dept. of Commerce, Washington, D.C., September 1981 .

4/ American Standards Association, "Through History with Standards" in Rowen $\bar{G}$ lie (ed.), Speaking of Standards, Cahner Books, Boston, MA, 1972, p. 38.

5/ Ibid., p. 42 .

6/ Ibid.. p. 44 .

I/ Rexmond C. Cochrane, Measures for Progress: A History of the National Bureau of Standards, National Bureau of Standards, U.S. Department of Commerce, Washington, D.C., pp. 82-86, 1974 .

8/ American Standards Association, p. 60 .

g/ Ibid.. p. 68 .

10/ Ibid., p. 50 .

11/ International Organization for Standardization, draft revision of Iso Guide 2. "General terms and their definitions concerning standardization, certification and testing laboratory accreditation," July 1985.

$12 /$ W. E. Andrus, Jr., Draft NBS Glossary of Terms for Product Standardization, Product Certification and Laboratory Accreditation, U.S. national Bureau of Standards, Dept. of Commerce, 1974.

13/ American Standards Association, p. 48.

14/ Bureau of Consumer Protection, Standards and Certiflcation: Final Staff Report - April 1983, Federal Trade Commission, Washington, D.C., Apr11, 1983, p. 2 .

15/ David A. Swankin, Rationale Statements for Voluntary Standards -- Issues, Techniques, and Consequences, National Bureau of Standards, Dept. of Commerce, Gaithersburg, MD, November, 1981 .

16/ International Organization for Standardization, Certification: Principles and Practice, International Organization for Standardization, Geneva, Switzerland, 1980 , p. 7 . 
17 Douglas B. Thomas, NVLAP Glossary of Terms for Laboratory Accreditation, Product Certification and Standardization, U.S. National Bureau of Standards, Washington, D.C. 1980 .

18/ Charles W. Hyer, Principal Aspects of U.S. Laboratory Accreditation

Programs, National Bureau of Standards, Gatthersburg, MD 20899, October 1984.

19/ Ibid. 21 . 
NBS.114A (REV. 2.8C)

U.S. DEPT. OF COMM.

BIBLIOGRAPHIC DATA

SHEET (See instructions)

1. PUBLICATION OR REPORT NO. NBSIR $87-3576$
2. Performing Organ. Report Nof 3. Publication Date

May 1987

4. TITLE AND SUBTITLE

The $A B C$ 's of Standards Related Activities in the United States

\section{5. $A U T H O R(S)$}

Maureen A. Breitenberg

6. PERFORMING ORGANIZATION (If joint or other than NBS, see instructions)

7. Contract/Grant No.

NATIONAL BUREAU OF STANDARDS

U.S. DEPARTMENT OF COMMERCE

GAITHERSBURG, MD 20899

8. Type of Report \& Period Covered

Final

9. SPONSORING ORGANIZATION NAME AND COMFLETE ADDRESS (Street, City, Stote, ZIF)

10. SUPPLEMENTARY NOTES

$\square$ Document describes a computer program; SF-185, FIPS Software Summary, is attached.

11. ABSTRACT (A 200-word or less factual summary of most significant information. If document includes a significant bibliogrophy or literature survey, mention it here)

This report provides an introduction to voluntary standardization, product certification and laboratory accreditation for a reader who is not fully familiar with these topics. It highlights some of the more important aspects of these fields; furnishes the reader with both historical and current information on these topics; describes the importance and impact of the development and use of standards; and serves as background for using available documents and services.

12. KEY WORDS (Six to twelve entries; alphabetical order; capitalize only proper names; and separate key words by semicolons) certification; inspection; laboratory accreditation; standardization; standards; testing

13. AVAILABILITY

[] Unlimited

$\square$ For Official Distribution. Do Not Release to NTIS

$\square$ Order From Superintendent of Documents, U.S. Government Printing Office, Washington, D.C. 20402.

区] Order From National Technical Information Service (NTIS), Springfield, VA. 2216I
14. NO. OF

PRINTED PAGES

23

15. Price

$\$ 9.95$ 

